\title{
A rare case of necrotizing sialometaplasia of palate treated with intralesional steroid injection
}

\section{Damakta intralezyonel steroid uygulaması ile tedavi edilen nadir bir nekrotizan sialometaplazi olgusu}

\author{
Bengu Cobanoglu ${ }^{1}$, Selcuk Arslan ${ }^{1}$, Ismail Saygin ${ }^{2}$ \\ ${ }^{1}$ Dept. of Otorhinolaryngology, Karadeniz Technical University, Faculty of Medicine, Trabzon, Turkey, ${ }^{2}$ Dept. of Pathology, Karadeniz Technical University, \\ Faculty of Medicine, Trabzon, Turkey
}

\begin{abstract}
Necrotizing sialometaplasia is a rare, benign, inflammatory disease of minor salivary glands and is similar in appearance to malignant lesions. A rare case of necrotizing sialometaplasia in palate treated with intralesional steroids is presented. A 65-year-old male patient had an ulcerated lesion of approximately $1 \times 2 \mathrm{~cm}$ in size near the midline in palate that had not healed for 2 weeks. The biopsy findings were in agreement with the diagnosis of necrotizing sialometaplasia. The patient was treated with a single dose of intralesional $40 \mathrm{mg}$ triamcinolone acetonide. At the end of the second week, the lesion was completely healed. Necrotizing sialometaplasia is an inflammatory disease that can mimic malignancies. Spontaneous healing is possible, and occurs from 4 to 10 weeks. Intralesional steroid administration can be considered as a treatment option that accelerates healing in this rare disease.
\end{abstract}

Key words: Necrotizing sialometaplasia, palate, inflammatory, intralesional, steroid

\section{O̊zet}

Nekrotizan sialometaplazi, minör tükrük bezlerinden kaynaklanan oldukça nadir, benign, inflamatuar bir hastalık olup görünüm olarak malign lezyonlara benzemektedir. İntralezyonel steroid ile tedavi edilen damak yerleşimli nadir bir nekrotizan sialometaplazi olgusu sunulmaktadır. Altmış beş yaşında erkek hastada 2 haftadır damağında iyileşmeyen orta hatta yakın yaklaşık 1x $2 \mathrm{~cm}$ boyutlu ülsere lezyon görüldü. Lezyondan alınan biyopsi sonucu nekrotizan sialometaplazi ile uyumlu olarak kaydedildi. Hastaya tek sefer intralezyonel $40 \mathrm{mg}$ triamsinolon asetonid tedavisi uygulandı. Tedavi sonrası ikinci haftada lezyonun tamamen iyileştiği izlendi. Nekrotizan sialometaplazi inflamatuar bir hastalık olup maligniteleri taklit edebilmektedir. Kendiliğinden iyileşme mümkün olup 4 ila 10 hafta arasında değişmektedir. İntralezyonel steroid uygulaması iyileşmeyi hızlandıran bir tedavi seçeneği olarak bu nadir hastalıkta göz önünde bulundurulabilir.

Anahtar kelimeler: Nekrotizan sialometaplazi, damak, inflamatuar, intralezyonel,steroid

Corresponding author: Bengu Cobanoglu, Dept. of Otorhinolaryngology, Karadeniz Technical University, Faculty of Medicine, Trabzon, Turkey Phone: +90 4623775147 Fax: +90 4623250518 E-mail:benguyc@gmail.com

Received: 30 May 2018 Accepted: 23 June 2018

Conflicts of Interest: None 


\section{Introduction}

Necrotizing sialometaplasia (NS) is a benign self-limiting inflammatory reaction of the salivary glands and may mimic clinical and histopathologic features of squamous cell carcinoma or mucoepidermoid carcinoma. ${ }^{1}$ Occasionally, misdiagnosis of malignancy can result in unnecessary surgical excisions with wide margins. ${ }^{2}$ This specific pathological lesion was first described by Abrams et al. ${ }^{2}$ in 1973 as the reactive necrotizing inflammation of minor salivary glands of hard palate. NS is more prevalent in white race and males and constitutes $0.03 \%$ of all oral cavity biopsies. ${ }^{3}$ The age range of the reported cases is between 17 and 80 years. The most commonsite of occurence is minor salivary glands of hard palate where as it can also be detected in mucosal tissues that harbour minor salivary glands such as retromolar trigon, gingiva, lips, tongue, buccal mucosa, nasal cavity, larynx and trachea. This spesific lesion was also reported in rare sites other than salivary glands such as lungs, mammary tissue and skin. ${ }^{4}$

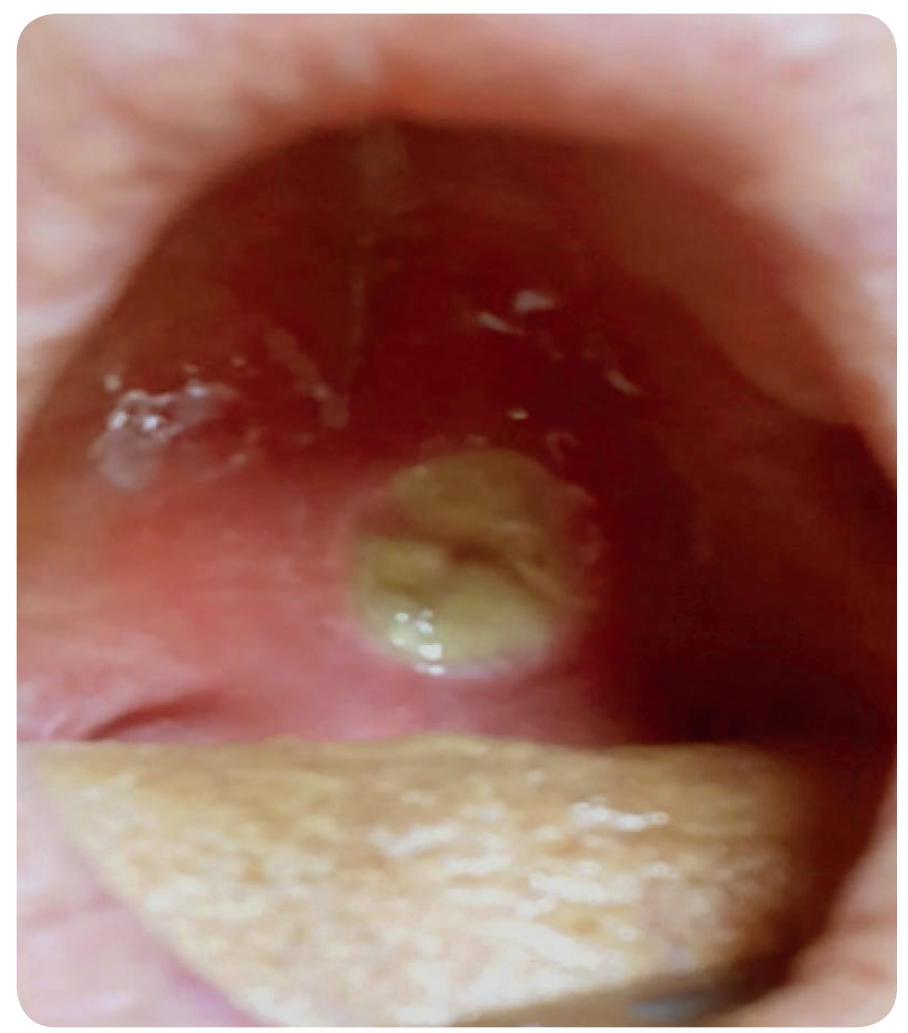

Fig. 1. Necrotic and ulcerated lesion of $1 \times 2 \mathrm{~cm}$ of size in palate

\section{Case report}

A 65-year-old male patient was admitted to our clinic with the complaint of an ulcer in his palate that had not healed for 2 weeks. He did not have pain or fever. The patient had a history smoking 1 packet of cigarettes a day for 40 years. In oral cavity examination an ulcerated lesion of approximately $2 \mathrm{~cm}$ in widest dimension involving the mucosal junction of hard and soft palate was detected (Fig. 1). The necrotic and ulcerated lesion with endurated margins had an appearance of a malignant lesion. Neck examination did not reveal any palpable mass. The histopathological examination of the incisional biopsy material showed clusters of inflammatory cells, necrotic areas in connective tissues and squamous hyperplasia in ductal epithelium of minor salivary glands (Fig. 2). A diagnosis of necrotizing sialometaplasia was made based on the histopathological and clinical findings. The patient was treated with a single dose of $40 \mathrm{mg}$ intralesionel triamsinolone acetate and complete healing was achieved at the end of 2 weeks (Fig. 3).

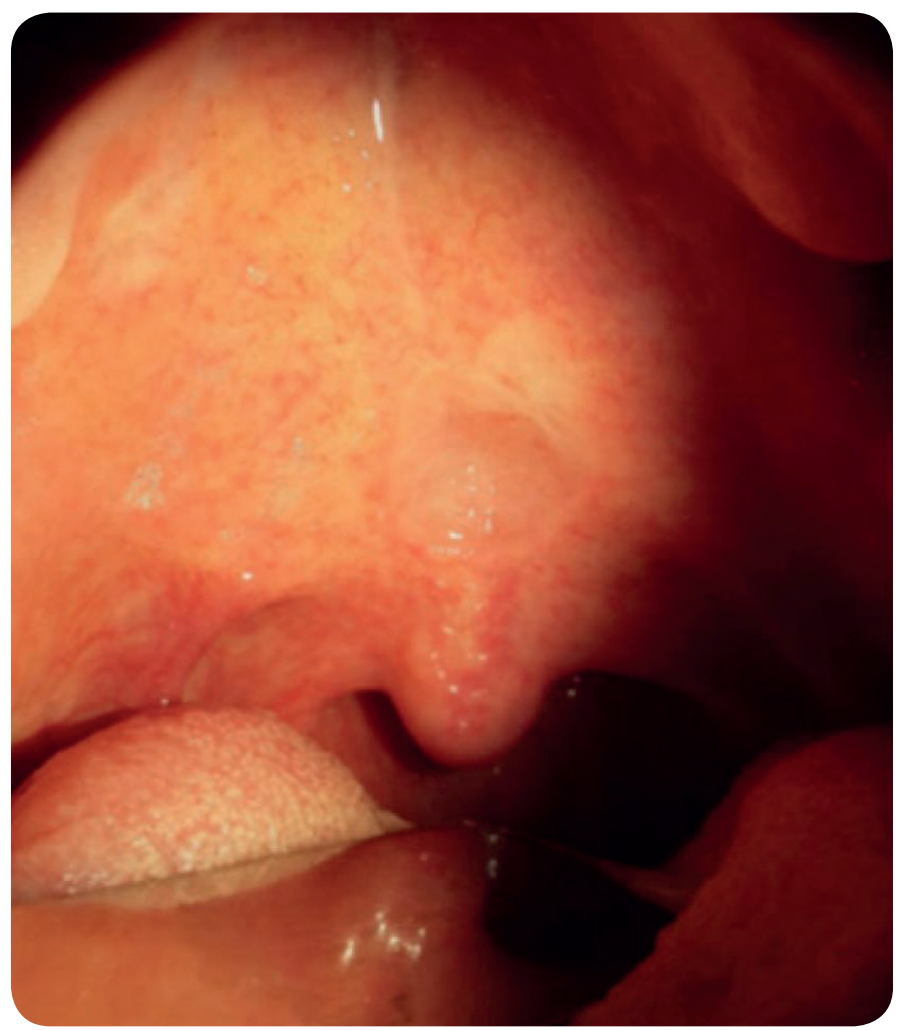

Fig. 3. The healed lesion 2 weeks after intralesionel steroid injection 


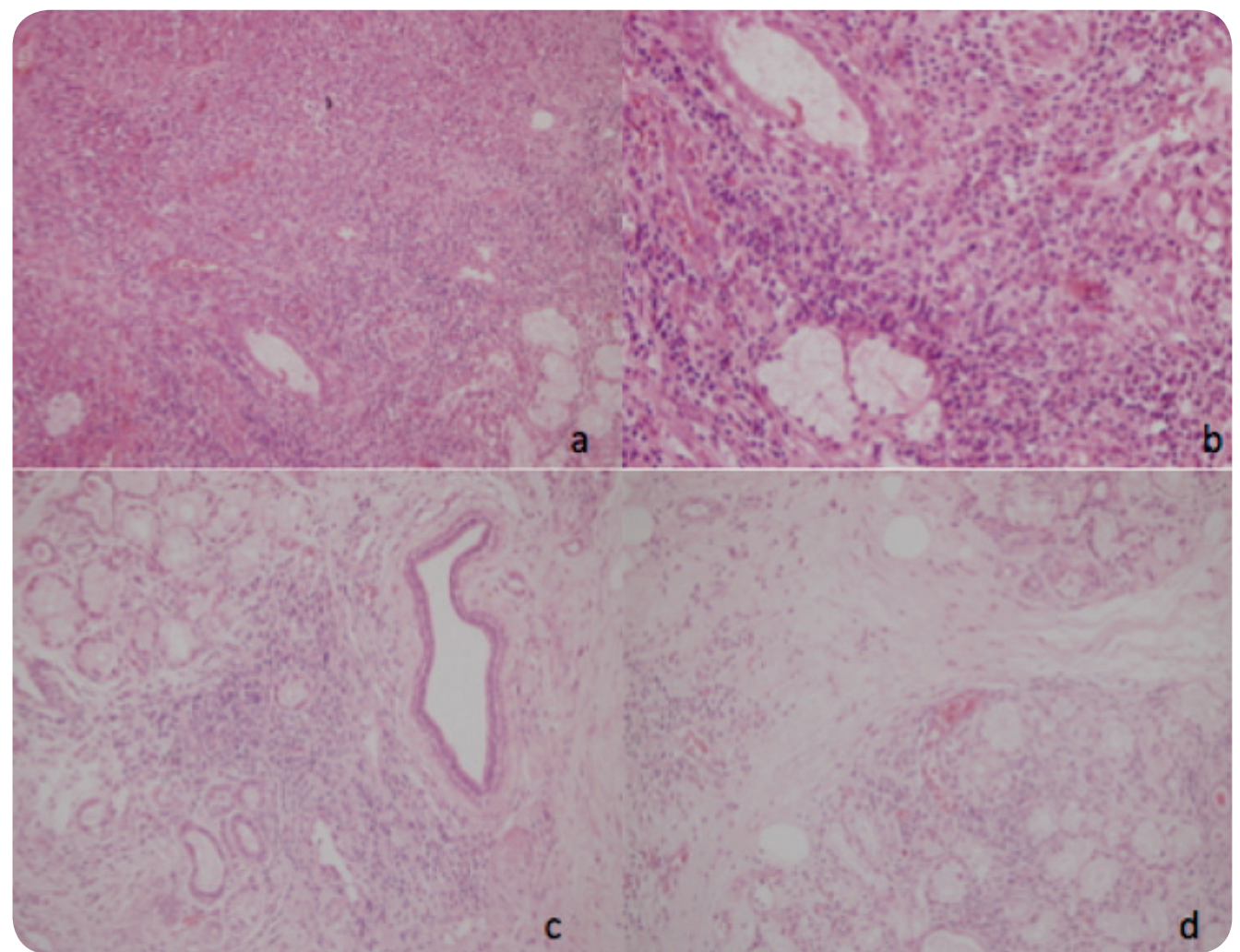

Fig. 2. Healthy structures of salivary gland on right inferior HE X200 (a), same area with high magnification HE X400 (b), inflammation with healthy ductus showing fibrosis HE X200 (c-d)

\section{Discussion}

NS is characterized by squamous metaplasia of ductal and acinar cells and lobular necrosis of salivary glands most commonly found in hard palate. Although the pathogenesis is unknown, an ischemic process that affects salivary gland lobules is thought to be implicated in etiology. Direct trauma, local anesthetic infiltration, inappropriate dental prostheses, alcohol, smoking, cocaine use and intubation are among the factors leading to ischemia. Long-term use of salbutamol leads to dehydration and thinning of the mucosa, rendering it to become more susceptible to local trauma. ${ }^{5}$ In our case dental prosthesis and cigarette smoking were the possible risk factors.

Various neoplastic and non-neoplastic lesions such as primary adenocarcinoma of the palate, squamous cell carcinoma, subacute necrotizing sialadenitis, aphthous ulcer, mucoepidermoid carcinoma, secondary sarcoma, and tuberculosis should be included in the differential diagnosis of necrotizing sialometaplasia.
NS occurs spontaneously and the initial symptoms are usually fever, fatigue or swelling. The hard palate is the most frequently affected area in NS, and the lesion is found in the intersection of the soft palate and the hard palate as seen in our case. Approximately two-thirds of these lesions are unilateral. However, bilateral synchronous and metachronous lesions are not uncommon. Lesions may develop in the midline on palate. ${ }^{6}$ The lesion size ranged from 0.7 to $5 \mathrm{~cm}$ with an average of $1.8 \mathrm{~cm}{ }^{7}$ A complete clinical history and appropriately taken biopsy sections are required for accurate diagnosis. Histopathological and clinical findings are useful to reach the diagnosis. NS is characterized by lobular necrosis and ductal and acinar metaplasia. Typically, there is an inflammatory infrastructure. On the surface, pseudoepitheliomatous hyperplasia and deeply located metaplasic squamous hyperplasia areas frequently lead to misdiagnosis of squamous cell carcinoma. Residual mucous cells with ductal and acinar squamous metaplasia may also suggest mucoepidermoid carcinoma. In most cases, 
preservation of the lobular structure, necrosis areas, and mixed inflammatory cell substrate are the distinguishing features of NS. ${ }^{8}$

Although these diagnostic criteria are distinctive, the diagnosis of this lesion requires special attention to avoid misdiagnosis and unnecessary aggressive treatment. In most cases, treatment is not needed and the lesion heals as a secondary process in 4-10 weeks (mean 5.2 weeks). Even lesions opening to the nasal cavity with full coverage of the gum are fully healed within 6 months. ${ }^{3}$ Intra-lesional triamcinolone acetonide $(40 \mathrm{mg}$ ) was administered as a single dose in our case. After 2 weeks of treatment, the lesion was completely healed. Considering the natural course of the disease, it can be predicted that intralesionel steroid treatment accelerates healing and decreases the associated morbidity.

NS is a self-limiting lesion of the salivary gland, usually involves hard palate and mimicks malignancy as a clinical presentation. Misdiagnosis as malignancy leads to unnecessary aggressive surgery. Careful examination of the pathological features of this disease is very important in reaching the correct diagnosis. While cure is possible without any treatment, intralesional steroid therapy can be used as a treatment option that shortens the healing period and reduces morbidity.

\section{References}

1. Mesa ML, Gertler RS, Schneider LC. Necrotizing sialometaplasia: Frequency of histologic misdiagnosis. Oral Surg Oral Med Oral Pathol 1984;57:71-3.

2. Abrams AM, Melrose RJ, Howell FV. Necrotizing sialometaplasia. A disease simulating malignancy. Cancer 1973;32:130-5.

3. Brannon RB, Fowler CB, Hartman KS. Necrotizing sialometaplasia-A clinicopathologic study of sixty-nine cases and review of the literature. Oral Surg Oral Med Oral Pathol 1991;72:317-25.

4. Krishna S, BK R. Necrotizing sialometaplasia of palate: A case report. Imaging Sci Dent 2011;41(1):35-38.

5. Fowler CB, Brannon RB. Subacute necrotizing sialadenitis: Report of 7 cases and a review of the literature. Oral Surg Oral Med Oral Pathol Oral Radiol Endod 2000;89:600-9.
6. Daudia A, Murty GE. First case of full-thickness palatal necrotizing sialometaplasia. J Laryngol Otol 2002;116:219-20.

7. Nah KS, Cho BH, Jung YH. Necrotizing sialometaplasia: Report of 2 cases. Korean J Oral Maxillofac Radiol 2006;36:207-9.

8. Marx RE, Stern D. In: Oral and maxillofacial pathology a rationale for diagnosis and treatment. 1st eds. Quintessence Publishing Co, Inc, New Delhi 2003;509-10. 